\title{
Hemoglobin B Measurement
}

National Cancer Institute

\section{Source}

National Cancer Institute. Hemoglobin B Measurement. NCI Thesaurus. Code C92260.

The determination of the amount of hemoglobin B present in a sample. 